Комунальний заклад “Рівненська обласна клінічна лікарня” Рівненської обласної ради, ДВНЗ “Тернопільський державний медичний університет імені І. Я. Горбачевського МОЗ Украӥни”

\title{
ОСОБЛИВОСТІ ЕМОЦІЙНОЇ СФЕРИ МЕДИЧНИХ ПРАЦІВНИКІВ
}

\author{
T. V. Pavlyuk, T. I. Tolokova \\ Municipal Institution "Rivne Regional Clinical Hospital” of Rivne Regional Counsel, \\ I. Horbachevsky Ternopil State Medical University
} FEATURES OF THE EMOTIONAL SPHERE OF MEDICAL WORKERS

\begin{abstract}
Мета роботи. Стаття присвячена вивченню особливостей емоційної сфери медичних працівників. Зміни в емоційній сфері медиків пов'язані з емоційними та етичними перевантаженнями в професійній діяльності. У медичній освіті необхідно акцентувати увагу на тренінгу адаптаційних можливостей емоційної сфери.

Основна частина. У статті окреслена проблематика пов’язана з факторами ризику, сильною емоційною напругою, відсутністю достатніх умов для відновлення сил, недостатністю психологічного супроводу у практиці системи охорони здоров'я, що несприятливо впливають на медичних працівників. Однією з найважливіших якостей медичного працівника є емоційна стійкість. Ключовим виявом емоційного стану особистості є настрій. Емоційне відчуття або настрій - це своєрідний акумулятор всієї інформації, яка сприймається і переробляється індивідом за відповідний час. Внаслідок цього настрій стає тривалим емоційним станом, що створюється зовнішніми впливами на особистість залежно від її індивідуальних особливостей і темпераменту. Нестабільність настрою медичного працівника, як правило, пов’язана не лише безпосередньо з тією або іншою конкретною медичною ситуацією, а й з комплексом найрізноманітніших вражень від зовнішніх чинників, роздумів і переживань. На настрій будь-якої особистості впливають ті чи інші життєві турботи, занепокоєння, викликані певними надзвичайними обставинами, ображене самолюбство, докори сумління. Будь-яка з цих емоцій або їхнє поєднання можуть бути помітні пацієнтам і заважати нормальній діяльності фахівця. I якщо медичний працівник не в змозі подолати такий настрій, то це може спричинити прийняття неправильного рішення, здійснення хибних медичних дій, створення напружених відносин із пацієнтами.

Висновки. Виникла необхідність сформувати у майбутніх медичних працівників готовність до емоційного співпереживання і співчуття стосовно проблем у сфері здоров’я пацієнтів. Розглянуто основні характеристики і встановлено чинники, які зумовлюють порушення емоційної сфери у медичних працівників. Вивчення емоційної сфери - важливе теоретичне і практичне завдання, що вимагає поглибленого дослідження, зорієнтованого на практику, що потребує подальшої розробки.
\end{abstract}

Ключові слова: емоційна сфера; настрій; співпереживання; медична освіта.

The aim of the work. The article is devoted to the study of the peculiarities of the emotional sphere of medical workers. Changes in the emotional sphere of physicians are associated with emotional and ethical overload in professional activity. In medical education it is necessary to focus attention on the training of adaptive possibilities of the emotional sphere.

The main body. The article outlines the problem of risk factors, severe emotional stress, lack of adequate conditions for recreation, lack of psychological support in the practice of the health system adversely affecting of medical workers. One of the most important qualities of a health worker is emotional stability. A key manifestation of the emotional state of the individual is the mood. Emotional mood is a kind of battery of all information that is perceived and processed by the individual at the appropriate time. As a result, the mood becomes a prolonged emotional state, created by external influences on the individual, depending on its individual characteristics and temperament. The instability of the mood of the medical worker, as a rule, is connected not only directly with one or another specific medical situation, but also with the complex of the most varied impressions from external factors, thoughts and experiences. The mood of any person is influenced by those or other vital concerns, concerns, caused by certain extraordinary circumstances, offended by selfishness, reproaching of conscience. Any of these emotions or their combination may be noticeable to patients and interfere with the normal activities of a specialist. And if the health worker is not able to overcome this mood, it can lead to wrong decision making, misleading medical actions, and creating tense relationships with patients.

Conclusions. There is a need to form future health professionals readiness for emotional empathy and compassion regarding health problems in patients. The main characteristics are considered and the factors that determine emotional disturbances in health care workers are established. The study of the emotional sphere is an important theoretical and practical task, which requires in-depth, practice-oriented research, which needs further elaboration.

Key words: emotional sphere; mood; empathy; medical education.

Вступ. Сучасна реформа системи охорони здоров’я, запровадження страхової медицини, ін-

(с) Т. В. Павлюк, Т. І. Толокова теграція України в європейське співтовариство потребують удосконалення системи медичної освіти з метою підготовки фахівців, які відповідали б сві- 
товим стандартам. Підвищення якості професійної підготовки фахівців охорони здоров’я потребує упровадження сучасних концепцій і наукових підходів, посилення акценту на формуванні не лише професійної компетентності, а й особистісних якостей та емоційної сфери медичних працівників.

Робота фахівців медичної галузі відноситься до професій, у яких особистість пов’язана з неминучими емоційними й етичними перевантаженнями, що призводять до внутрішньої емоційної спустошеності внаслідок необхідності постійних контактів із хворими людьми. Адже робота лікаря чи медичної сестри пов'язана з людськими стражданнями, смертю, колосальними навантаженнями на нервову систему, високою відповідальністю за життя і благополуччя інших людей. Постійні стресові ситуації, в які потрапляють медичні працівники в процесі складної соціальної взаємодії з пацієнтами, необхідність сприйняття й усвідомлення сутності проблем пацієнта, особистісна незахищеність та інші морально-психологічні чинники негативно впливають на здоров’я фахівця медицини [1].

Професійна діяльність медичних працівників супроводжується також психоемоційним напруженням, що зумовлено періодичним порушенням добових біоритмів, пов'язаних із роботою в різні зміни (день - ніч). Окрім того, до психологічних чинників ризику відносяться побоювання професійного інфікування, часті ситуації, пов’язані з проблемами спілкування (надмірно стурбовані пацієнти, вимогливі родичі тощо). Існує ще низка чинників, які підсилюють надмірну професійну напругу: незадоволеність результатами праці (відсутність умов для ефективного надання допомоги, матеріальної зацікавленості), завищені вимоги до медиків, необхідність поєднання професійних і сімейних обов’язків [2]. Відтак виникає необхідність сформувати у майбутніх медичних працівників готовність до емоційного співпереживання і співчуття стосовно проблем у сфері здоров’я пацієнтів.

Дослідження деяких особливостей емоційної сфери особистості медичних працівників представлені в публікаціях В. Бойко, В. Вілюнас, Н. Греса, Т. Гузенко, Є. Старченкова, В. Юрьєва та ін., котрі двояко розглядають емоційну сферу фахівців медичної галузі: як чинник професійної відповідності та сферу, яка найбільш схильна до професійних деформацій. У науковому тезаурусі проблема емоційної сфери досліджується у поєднанні компонентів емоційної сфери з пізнавальними процесами
(Л. Виготський, О. Леонтьєв), мотивами, потребами (К. Ізард, С. Рубінштейн, С. Шехтер), вольовими процесами (Л. Божович, 3. Фрейд, Я. Рейковський та ін.). Однак в умовах нестабільної соціальної економічної ситуації, високого емоційного навантаження і вимог до фізичної працездатності медичних працівників виникає потреба в проведенні численних експериментальних досліджень із метою вивчення особливостей емоційної сфери медиків.

Мета роботи. Стаття присвячена вивченню особливостей емоційної сфери медичних працівників. Зміни в емоційній сфері медиків пов'язані з емоційними та етичними перевантаженнями в професійній діяльності. У медичній освіті необхідно акцентувати увагу на тренінгу адаптаційних можливостей емоційної сфери.

Основна частина. Актуальність проблеми вивчення особливостей емоційної сфери майбутніх медичних працівників пояснюється тим, що саме емоції є “індикатором” психологічного стану особистості та істотно впливають на перебіг психічних процесів і поведінки людини, визначаючи спрямованість уваги, особливість сприйняття навколишнього світу, логіку суджень [3]. На особливу увагу заслуговує проблема збереження емоційного здоров’я фахівців тих професій, які мають найбільшу кількість стрес-чинників, серед яких провідне місце посідають медичні працівники.

Наявність чинників ризику, сильна емоційна напруга, відсутність достатніх умов для відновлення сил, відсутність у практиці охорони здоров'я системи психологічного супроводу несприятливо впливають на медичних працівників. Збільшення нервовопсихічної напруги в роботі медиків призводить до виникнення у них невротичних розладів, психосоматичних захворювань. Тому вивчення проблеми емоційних переживань особистості в умовах професійного стресу зосереджується в точці перетину багатьох дисциплін: від фізіології і медицини до психології, соціології та політики. Це зумовлено, $з$ одного боку, фізіологічними і психологічними механізмами стрес-реакцій, а 3 іншого - соціальним характером наслідків професійних стресів. Вимоги, що пред'являються до емоційної сфери медичних працівників, досить суперечливі. Поряд з емпатійністю і толерантністю вони повинні бути й емоційно стійкими, а надмірна емоційність та загальмованість $є$ перешкодою для здійснення чітких і швидких дій.

Своєрідність “допомагаючих” професій полягає в тому, що сам суб’єкт діяльності є первинним інстру- 
ментом своєї роботи, а медична діяльність вимагає від фахівця особистісної залученості, відкритості відносин, уміння співпереживати і співчувати, а також здатності розуміти інтереси пацієнта [4]. Наприклад, професія медичної сестри висуває певні вимоги до ії особистості, характеру, емоційної сфери, а також до морально-етичних якостей. Адже медична діяльність вимагає від фахівців сестринської справи не лише глибоких знань своєї спеціальності і лікувальних дій, а й різнобічної культури, широти інтелекту, особливих навичок поведінки в спілкуванні з пацієнтами. Воля, енергія, бажання працювати, гуманізм та інтелект - все це необхідно кожному медику, однак лише цих якостей недостатньо.

Серед властивостей, що мають професійну значущість і характеризують емоційну сферу медичних працівників, є пластичність поведінки, здатність розуміти інших, емоційність, емпатія, людяність, уміння встановлювати контакт із пацієнтами та завойовувати у них довіру, соціальна зрілість особистості, емоційна стійкість, саморегуляція тощо. Адже медичний працівник повинен вміти завоювати симпатію пацієнта, виявляти м'якість і душевність до нього, увагу і співчуття. Впевненість пацієнта в досвідченості медичного персоналу значною мірою забезпечує позитивний результат лікування. Довіра пацієнта до медичного працівника - необхідна умова в комплексі лікувальних заходів та показник нормальних взаємин. У таких випадках пацієнти, зазвичай, погоджуються на будь-які методи дослідження і лікування.

Важливою складовою емоційної сфери медичних працівників є стан постійної готовності надати допомогу, вміння за першої необхідності мобілізувати всі свої сили, які супроводжуються високим почуттям професійного обов'язку та усвідомленням неможливості залишити страждаючого пацієнта без медичної допомоги [5]. Зауважимо, що характер емоційних хвилювань медика змінюється шляхом формування в нього соціальних мотивів діяльності (прагнення зробити дещо необхідне, корисне не лише для себе, а й для інших). Під впливом подібної діяльності в особистості формуються нові мотиви поведінки, а відтак виникають нові емоційні переживання [6].

Важливою ознакою в професійній діяльності медичних працівників є вияв співчуття до пацієнта. Однак ці почуття повинні відступати на другий план перед зосередженістю волі і розуму, знань і вмінь під час виконання медичних маніпуляцій, щоб лікувальні дії дали бажаний результат. Адже фахівець медичної справи повинен бути завжди зібраним, холоднокровним, не “втрачати голови”, вміти “відключатися” від всього, що може завадити виконанню лікувального завдання [7].

Необхідно окреслити ще однин аспект спрямованості професійної діяльності фахівців медичної сфери - самосвідомість, що сприяє усвідомленню медика себе як особистості і професіонала у власних відносинах із зовнішнім світом та іншими людьми. Самосвідомість виявляється в різних формах. Так, самоаналіз, самооцінка, самокритика пов'язані 3 пізнавальною стороною психічної діяльності особистості, тоді як самопочуття, самолюбство, самовихваляння, самовпевненість, скромність, почуття відповідальності, обов'язку, власної гідності пов’язані з емоційною стороною психічної діяльності особистості. Саме стриманість, самовладання, самоконтроль, ініціатива, самодисципліна пов'язані з вольовою стороною психічної діяльності медиків.

Однією з найважливіших якостей медичного працівника $є$ емоційна стійкість. Ключовим виявом емоційного стану особистості є настрій. Відзначаючи значення настрою як чинника соціальної орієнтації та діяльності особистості, Н. Маклакова зазначала, що ні слова, ні думки, ні навіть вчинки не виявляють так вірно нас самих і наші ставлення до світу, як наш настрій: у ньому відображається характер не окремої думки, не окремого рішення, а всього змісту душі [3]. Настрій - це свого роду акумулятор всієї інформації, яка сприймається і переробляється індивідом за одиницю часу. Тому настрій $€$ тривалим емоційним станом, що створюється зовнішніми впливами на особистість залежно від її індивідуальних особливостей і темпераменту. Нестійкість настрою медичного працівника, зазвичай, пов'язана не лише безпосередньо з тією або іншою конкретною медичною ситуацією, а й 3 комплексом найрізноманітніших вражень від зовнішніх чинників, роздумів і переживань. На настрій будь-якої особистості впливають ті чи інші життєві турботи, занепокоєння, викликані певними надзвичайними обставинами, ображене самолюбство, докори сумління. Будь-яка 3 цих емоцій або їхнє поєднання можуть бути помітні пацієнтам і заважати нормальній діяльності фахівця. I якщо медичний працівник не в змозі подолати такий настрій, то це може спричинити прийняття неправильного рішення, здійснення хибних медичних дій, створення напружених відносин із пацієнтами. 
Ставлення медичного працівника до пацієнта не може визначатися лише емоціями. Поведінка медика, особливо коли він змушений діяти швидко і рішуче, інколи здається пацієнтам та їхнім родичам байдужою, а сам медичний працівник - відчуженим і холодним. Для гуманного ставлення медичного працівника до пацієнтів оптимальним є вияв розуміння їхнього суб’ єктивного стану, чуйне, але не багатослівне співчуття, ніж повне і явне злиття з фізичним чи душевним болем до такої міри, щоб медик сам почав переживати емоційний шок.

Висновки. На основі аналізу особливостей емоційної сфери медичних працівників можемо стверджувати, що для фахівців медичної галузі важливими є особисті якості, які дають змогу ефективно справлятися зі стресогенними чинниками. Важливо, щоб медик умів керувати власними емоціями, зберігати впевненість, контролювати свої реакції і професійну поведінку в цілому. Терпіння і ввічливість - складові елементи хорошого стилю роботи, в них виявляються дбайливість і увага до пацієнтів. Медичні працівники повинні відчувати, коли їм необхідно віддалитися від пацієнта, а коли ж най-

\section{Список літератури}

1. Андрійчук О. Я. Виховання гуманності у студентів медичного коледжу в процесі фахової підготовки : автореф. дис. на здобуття наук. ступеня канд. пед. наук : спец. 13.00.07 “Теорія і методика виховання” / О. Я. Андрійчук. - К., 2003. - 21 с.

2. Лазуренко О. О. Тренінг формування емоційної компетентності майбутнього лікаря / О. О. Лазуренко // Fundamental and Applied Researches In Practice of Leading Scientific Schools. - 2016. - № 2 (14). - C. 44-54.

3. Маклакова Н. В. Эмоциональный интеллект как интегративный показатель целостного развития личности / Н. В. Маклакова // Вестник КГУ. - 2015. C. $112-115$.

\section{References}

1. Andriichuk, O.Ya. (2003). Vykhovannia humannosti u studentiv medychnoho koledzhu v protsesi fakhovoi pidhotovky [Humanity formation among college students in the process of professional training]. Extended abstract of Candidate's thesis. Kyiv [in Ukrainian].

2. Lazurenko, O.O. (2016). Treninh formuvannia emotsiinoi kompetentnosti maibutnoho likaria [Training for the formation of emotional competence of the future doctor]. Fundamental and Applied Researches In Practice of Leading Scientific Schools, 2 (14), 44-54 [in Ukrainian]. більш наблизитися до нього. Важливими є і вияв поваги до пацієнтів, уміння адекватно будувати взаємини $з$ ними, домагаючись, водночас, оптимального вирішення професійних завдань. Знання етико-деонтологічних принципів і законів психології професійного спілкування у поєднанні з професійною майстерністю медичних працівників, які здобуваються під час отримання медичної освіти, сприятимуть наданню ефективної медичної допомоги навіть у найважчих випадках.

Перспективним напрямом досліджень проблеми емоційної сфери медичних працівників є розробка та впровадження відповідних програм, методичних рекомендацій із метою оптимізації процесу особистісного становлення фахівців медицини у професійній діяльності, створення психологопедагогічної моделі супроводу формування емоційної сфери фахівця-медика тощо. Вивчення емоційної сфери - важливе теоретичне і практичне завдання, що вимагає поглибленого дослідження, зорієнтованого на практику, що потребує подальшої розробки і впровадження в освітній процес.

4. Греса Н. В. Особливості емоційної сфери працівників станції швидкої допомоги / Н. В. Греса // Вісник Харківського національного університету. - 2011. № 937. - С. 48-51.

5. Бобер Е. А. Специфика профессиональных личностных особенностей студентов медицинского колледжа как фактор качества подготовки специалиста / Е. А. Бобер // Молодой учёный. - 2013. - № 3 (50). - С. 460-463.

6. Лазуренко О. О. Аналіз психологічних особливостей складових емоційної компетентності майбутнього лікаря / О. О. Лазуренко // Психологічний часопис. 2016. - № 2 (4). - С. 96-111.

7. Полянцева О. И. Психология для средних медицинских учреждений / О. И. Полянцева. - М. : Феникс, 2008. - 416 c.

3. Maklakova, N. V. (2015). Emotsionalnyy intellekt kak integrativnyy po- kazatel tselostnogo razvitiya lichnosti [Emotional intelligence as an integrative indicator of holistic personality development]. Ezhegodnyy Vestnik KGU Annual Bulletin of the KSU, 2015, 112-115 [in Russian].

4. Hresa, N.V. (2011). Osoblyvosti emotsiinoi sfery pratsivnykiv stantsii shvydkoi dopomohy [Features of emotional sphere of ambulance workers]. Visnyk Kharkivskoho natsionalnoho universytetu - Bulletin of Kharkiv National University, 937, 48-51 [in Ukrainian]. 
5. Bober, Ye.A. (2013). Spetsifika professionalnykh lichnostnykh osobennostey studentov meditsinskogo kolledzha kak faktor kachestva podgotovki spetsialista [Specificity of professional personal characteristics of medical college students as a factor in the quality of specialist training]. Molodoy uchenyy - Young Scientist, 3 (50), 460463 [in Russian].
6. Lazurenko, O.O. (2016). Analiz psykholohichnykh osoblyvostei skladovykh emotsiinoi kompetentnosti maibutnoho likaria [Analysis of psychological peculiarities of the emotional competence of the future doctor]. Psykholohichnyi chasopys - Psychological Journal, 2 (4), 96-111 [in Ukrainian]. 7. Polyantseva, O.I. (2008). Psikhologiya dlya srednikh meditsinskikh uchrezhdeniy [Psychology for secondary medical institutions]. Moscow: Feniks [in Russian].

Отримано 26.01.18

Електронна адреса для листування: tolokova@tdmu.edu.ua 